\title{
The Examination of Some Physical and Biomotor Parameters During the European Championship Preparation Camp of Turkey National Junior Women Boxing Team*
}

\author{
Raif Zileli ${ }^{1}$, Mehmet Söyler ${ }^{2}$ \\ ${ }^{1}$ Bilecik Seyh Edebali University, School of Health, Bilecik, Turkey \\ ${ }^{2}$ Çankırı Karatekin University, Yapraklı Vocational School, Çankırı, Turkey \\ Correspondence: Raif Zileli, School of Health, Bilecik Seyh Edebali University, Bilecik, Turkey.
}

Received: June 11, $2018 \quad$ Accepted: July 17, $2018 \quad$ Online Published: July 18, 2018

doi:10.11114/jets.v6i9.3326 URL: https://doi.org/10.11114/jets.v6i9.3326

\begin{abstract}
The aim of this study is to examination of some physical and biomotor parameters of Turkey National Junior Women Boxing Team during six-week training camp before European Championship.

27 boxers from Turkey National Junior Women Boxing Team participated in the research. The age of the boxers was $\bar{x}=15.85 \pm 0.45$ years, the height of boxers was $\bar{x}=163.00 \pm 6.08 \mathrm{~cm}$ and the body weight of boxers was $\bar{x}=63.78 \pm 14.30 \mathrm{~kg}$. Boxers participating in the study were given a 6-week training program prepared and scheduled by Turkey Boxing Federation. Some physical and biomotorical parameters (body weight, BMI, body fat percentage, 10 meters speed, 30 meters speed, vertical jump, anaerobic power) of all boxers were measured at the beginning and at the end of the camp. Statistical processes of all data were analysed by SPSS 17.0 statistical package program. Normal distribution analyses were performed with the Shapiro-Wilk Test. Pre-test and post-test comparison of Body Mass Index and body weight values were analyzed by using the Wilcoxon Test and, pre-test and post-test comparison of body fat percentages, $10 \mathrm{~m}$. speed, $30 \mathrm{~m}$. speed, vertical jump and anaerobic power values were analyzed by using the Paired $\mathrm{T}$ test statistic. Significance value was taken as $\mathrm{p}<0.05$.

Changes in body weight values before and after camping were $\bar{x}=63.78 \pm 14.35 \mathrm{~kg}-\overline{\mathrm{x}}=61.25 \pm 14.31 \mathrm{~kg}$, in BMI values $\bar{x}=23.09 \pm 5.44 \mathrm{~kg} / \mathrm{m}^{2}-\bar{x}=21.86 \pm 4.45 \mathrm{~kg} / \mathrm{m}^{2}$, in body fat percentages $\bar{x}=26.91 \pm 9.50-\bar{x}=25.61 \pm 9.29$, in $10 \mathrm{~m}$ speed values $\bar{x}=3.03 \pm 0.25-\bar{x}=2.93 \pm 0.23 \mathrm{sec}$, in $30 \mathrm{~m}$ speed values $\bar{x}=6.44 \pm 0.36-\bar{x}=6.25 \pm 0.34 \mathrm{sec}$, in vertical jump values $\overline{\mathrm{x}}=0.21 \pm 0.09$ to $\overline{\mathrm{x}}=0.31 \pm 0.07 \mathrm{~m}$ and in anaerobic power $\overline{\mathrm{x}}=63.71 \pm 20.13-\overline{\mathrm{x}}=74.47 \pm 15.48 \mathrm{kgm} / \mathrm{s}$, significant changes were seen statistically $(\mathrm{p}<0.05)$.
\end{abstract}

As a result we suggest that the having a well-designed training camp can make a positive contribution on physical and biomotor parameters of national junior women boxers before an important tournament.

Keywords: anaerobic power, boxing, vertical jump, $10 \mathrm{~m}$ speed, $30 \mathrm{~m}$ speed

\section{Introduction}

Physical, physiological conformity is required to achieve successful performance in the sport. The physical and physiological characteristics of the athlete cannot realize the desired sporting performance exactly unless it is suitable for the sport branch. However, physical fitness is not the only important condition for high performance. (Devecioğlu and Pala, 2010). Performance in sport depends on many factors such as aerobic and anaerobic energy capacity, speed and technique, neuromuscular functions, tactics and psychology (Aydaş et al., 2002). Modern boxing is originated in England and is known as one of the world's most popular fighting sports (Pala and Savci, 2011). Boxing sport has a combined structure due to its high level of dynamic and static application characteristics in the competition and it is among the fight sports that require high level of power (Aydaş et al., 2002). In boxing sport, as well as technical and tactical training, aerobic and anaerobic power are basically physical and physiological elements affecting speed,

\footnotetext{
${ }^{*}$ This research was presented at the International Congress of Sports for All and Wellness between 05-08 April 2018, Antalya, Turkey.
} 
endurance, body fat ratio, flexibility, coordination, skill and success (Savaş and Uğraş, 2004). The aim of the study is to examine some of physical and biomotor parameters of Turkey National Junior Women Boxing Team during six weeks of training camp period before the European Championship and to compare and discuss obtained data with the previous literature.

\section{Method}

\subsection{Participants}

27 boxers from Turkey National Junior Women Boxing Team, whose age was $\bar{x}=15.85 \pm 0.45$ years, the height of boxers was $\bar{x}=163.00 \pm 6.08 \mathrm{~cm}$ and the body weight of boxers was $\bar{x}=63.78 \pm 14.30 \mathrm{~kg}$. The boxers voluntarily participated in this study. The measurements were taken in June and July 2017 at the European Championship preparatory camp in the province of Çankırı. The training camp having an intensive physical demand and nutrition program applied to boxers was prepared and scheduled by the General Directorate of Sports and Turkey Boxing Federation and it was held under supervision of technical director and trainers. The tests were repeated twice, once before the preparatory camp and second at the end of the camp.

Before the training camp started, all the athletes were informed about the research and informed consent forms were taken. The research we had done was approved by the Ethics Committee of Çankırı Karatekin University (2017 / 21533).

\subsection{Measurements}

Body weight and body fat percentage; were measured by using Tanita BC418 (Japan), the height was measured with $0.01 \mathrm{~m}$ sensitivity by using Holtaine (UK) brand stadiometer.

Body mass index; after body weight and height measurements were measured (WHO, 2008), BMI was calculated by the following formula.

Body Mass Index $=$ Body Weight $/$ Height $(\mathrm{m})^{2}$

Each boxers performed two trials having $10 \mathrm{~min}$ rest between trials in $10 \mathrm{~m}$ and $30 \mathrm{~m}$ Speed Test. The best of 2 trials was recorded as test score. Photocells were located at $0 \mathrm{~m}, 10 \mathrm{~m}$ and $30 \mathrm{~m}$ lines on test area. The speed tests were done on a tartan track. Sensitivity of photocell (Tümer Electronics) was 0.001 second.

The vertical jump test was performed using a vertical jump panel. The jump test was performed while feet were adjacent and the body was in a vertical position, both of arm of subject was extended up to the last point contacted by the fingertips. Then the subject were asked to jump vertically and touch to the panel with all their strength. In the vertical jump test subjects were not allowed to take any forward or backward steps. This process was repeated twice and the best of two trials was recorded as test score. (Tamer, 2000; Zorba and Saygin, 2009).

The Lewis formula was used by utilizing the athletic's anaerobic powers, vertical jump distance and body weight;

Anaerobic power $=$ body weight $(\mathrm{kg}) \times \sqrt{4.9 \times \mathrm{x}(\mathrm{m})} \quad(\mathrm{D}=$ Vertical Jump Distance) $($ Fox et al 1999).

The development rates (\%) of the athletes were calculated by formulating:

$\mid$ PreTestScore - PostTestScore $\mid=$ Difference

$\frac{\text { Difference }}{\text { PreTest Score }} \times 100=$ Development Rate $\%$

\subsection{Analysis of Data}

Statistical analysis of all obtained data was done by SPSS 17.0 statistical package program in computer. Normal distribution analyses were made with the Shapiro-Wilk test. Comparison of the pre-test and post-test scores of BMI and body weight data were analyzed by using the Wilcoxon Test. Comparison of the pre-test and post-test scores of body fat percentage, $10 \mathrm{~m}$ speed, $30 \mathrm{~m}$ speed, vertical jump and anaerobic power were analyzed by using the Paired $\mathrm{T}$ test. Significance value was taken as $\mathrm{p}<0.05$.

\section{Results}

Some characteristics of boxers (n: 27) participating in this study was $\bar{x}=15.85 \pm 0.45$ years, the height of boxers was $\overline{\mathrm{x}}=163.00 \pm 6.08 \mathrm{~cm}$ and the body weight of boxers was $\overline{\mathrm{x}}=63.78 \pm 14.30 \mathrm{~kg}$ (Table 1). 
Table 1. Age, height $(\mathrm{cm})$ and body weight $(\mathrm{kg})$ measurements of boxers

\section{$\overline{\mathrm{x}}$ : Mean; Sd: Standard deviation}

\begin{tabular}{lcc}
\hline Variables & $\overline{\mathrm{x}}$ & $\mathrm{sd}$ \\
\hline Age $($ years $)$ & 15.85 & 0.45 \\
\hline Height $(\mathrm{cm})$ & 163 & 6.08 \\
\hline Body Weight $(\mathrm{kg})$ & 63.78 & 14.30 \\
\hline
\end{tabular}

When Table 2 is examined, as a result of statistical analysis it was found that there is a statistically significant differences between pre-camp and post-camp measurements of boxers between body weight values $(\mathrm{t}=20.83, \mathrm{p}<0.05)$, BMI values $(t=3.92, p<0.05)$, body fat percentages values $(t=-5.63, p<0.05), 10 \mathrm{~m}$ speed values $(t=6.93, p<0.05)$, $30 \mathrm{~m}$ speed values $(\mathrm{t}=5.28, \mathrm{p}<0.05)$, vertical jump values $(\mathrm{t}=-6.95, \mathrm{p}<0.05)$ and anaerobic power values $(\mathrm{t}=-4.73, \mathrm{p}$ $<0.05)$ (Table 2).

Table 2. Physical and biomotor parameters of boxers before and after camp

\begin{tabular}{|c|c|c|c|c|c|c|c|}
\hline Variables & Measurements & $\overline{\mathrm{x}}$ & sd & Development Rate (\%) & $\mathrm{z}$ & $\mathrm{t}$ & $\mathrm{p}$ \\
\hline \multirow{2}{*}{ Body Weight(kg) } & Pre-Test & 63.78 & 14.35 & \multirow[t]{2}{*}{ 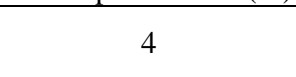 } & \multirow{2}{*}{-4.54} & \multirow[b]{2}{*}{-} & \multirow{2}{*}{$.00 *$} \\
\hline & Post Test & 61.25 & 14.31 & & & & \\
\hline \multirow{2}{*}{ BMI $\left(\mathrm{kg} / \mathrm{m}^{2}\right)$} & Pre-Test & 23.09 & 5.44 & \multirow{2}{*}{5} & \multirow{2}{*}{-3.95} & \multirow{2}{*}{-} & \multirow{2}{*}{$.01 *$} \\
\hline & Post Test & 21.86 & 4.45 & & & & \\
\hline \multirow{2}{*}{ Body Fat (\%) } & Pre-Test & 26.91 & 9.50 & \multirow{2}{*}{5} & \multirow[b]{2}{*}{-} & \multirow{2}{*}{5.63} & \multirow{2}{*}{$.00 *$} \\
\hline & Post Test & 25.61 & 9.29 & & & & \\
\hline \multirow{2}{*}{10 meters Speed (sn) } & Pre-Test & 3.03 & 0.25 & \multirow{2}{*}{3} & \multirow{2}{*}{-} & \multirow{2}{*}{6.93} & \multirow{2}{*}{$.00 *$} \\
\hline & Post Test & 2.93 & 0.23 & & & & \\
\hline \multirow{2}{*}{30 meters Speed (sn) } & Pre-Test & 6.44 & 0.36 & \multirow{2}{*}{3} & \multirow{2}{*}{-} & \multirow{2}{*}{5.28} & \multirow{2}{*}{$.00 *$} \\
\hline & Post Test & 6.25 & 0.34 & & & & \\
\hline \multirow{2}{*}{ Vertical Jump (m) } & Pre-Test & 0.21 & 0.09 & \multirow{2}{*}{48} & \multirow{2}{*}{-} & \multirow{2}{*}{-6.95} & \multirow{2}{*}{$.00 *$} \\
\hline & Post Test & 0.31 & 0.07 & & & & \\
\hline \multirow{2}{*}{ Anaerobic Power $(\mathrm{kgm} / \mathrm{sn})$} & Pre-Test & 63.71 & 20.13 & \multirow{2}{*}{17} & \multirow[b]{2}{*}{-} & \multirow{2}{*}{-4.73} & \multirow{2}{*}{$.00 *$} \\
\hline & Post Test & 74.47 & 15.48 & & & & \\
\hline
\end{tabular}

$* \mathrm{P}<0.05$

$\overline{\mathrm{x}}$ : Mean; Sd: Standard deviation

\section{Discussion}

This study was conducted to examine some of the physical and biomotor parameters of Turkey Star Women Boxing National Team during the six weeks of training camp before the European Championships.

It was determined that there was a statistically significant decrease in the body weight values of the athletes participating in the study $(\mathrm{p}<0.05)$. In our study, the average weight of pre-camp body weight of the athletes was 63.78 $\mathrm{kg}$, while it decreased to $61.25 \mathrm{~kg}$ after the training camp and the development rate was $4 \%$ (Table 2). One of the effective criteria in determining the performance of the sport is body weight (Savaş and Uğraş, 2005).

A study carried of with 16 elite boxers during 12-week training camp (11 of them was in Turkish National Team, 5 of them had the first three degree in the Turkish Championship, also some of them had success in the World and Europe championships) reported some changes and developments in some physical and respiratory parameters. It was stated that the body weight of boxers dropped from $70.93 \mathrm{~kg}$ to $70.73 \mathrm{~kg}$ (Çakmakçı et al., 2005). In another study comparing some physical parameters of professional handball players to national women boxers, it was reported that boxers had $56.35 \mathrm{~kg}$ average body weight (Çınar et al., 2009). Savaş and Uğraş investigated effects of a training camp on physical and physiological characteristics of university male boxing athletes and reported that 8-week pre-season training program reduced the body weight from average of $78.33 \pm 12.26 \mathrm{~kg}$ to $75.67 \pm 10.61 \mathrm{~kg}$ (Savaş and Uğraş, 2004). Our study findings which are similar to the literature can be explained by the fact that box sport has weight categories and in training camps most of the nutrition programs are under control in the European Championship preparation camp and boxers have weight anxiety.

A significant decrease was also found in the BMI values of the athletes participating in the study $(\mathrm{p}<0.05)$. In our study, while the average pre-camp BMI of the athletes was $23.09 \mathrm{~kg} / \mathrm{m}^{2}$, it was $21.86 \mathrm{~kg} / \mathrm{m}^{2}$ after camp and the development rate was $5 \%$ (Table 2). Pala and Savucu (2011) found that boxer's BMI values were $22.11 \mathrm{~kg} / \mathrm{m}^{2}$ before camping and were $22.19 \mathrm{~kg} / \mathrm{m}^{2}$ after camp. Çınar et al., (2009) examined Turkish and Ukrainian Boxing National Teams and stated that Turkish Boxing National Team's average BMI was $22.83 \mathrm{~kg} / \mathrm{m}^{2}$ (Çınar et al., 2009). Devecioğlu and Pala (2010) investigated boxer's body composition to determine their contribution levels to performance and they examined the 
"Correlation Between BMI Values and Sportive Achievements" of boxers participating in the World Universities Boxing Championships, $52.3 \%$ of successful boxers and $48.2 \%$ of unsuccessful boxers were in the "15.80-21.47" body mass index range. Our findings are similar to the literature and the BMI values of the athletes are within normal limits. These results are normal, because BMI depends on body weight and if there is a decrease in body weight, BMI would decrease too.

Another finding obtained as a result of our work is the body fat percentage of the athletes. The average pre-camp body fat rate of the athletes decreased from $26.91 \%$ to $25.61 \%$ after the camp, and it is seen that the development rate was $5 \%$ (Table 2). Pala and Savucu (2011) stated that there was no statistically difference in the average body fat rate of the boxing group which was $12.32 \%$ before and then was $12.33 \%$. In a study comparing some physical parameters of professional handball players with national women boxers, it was reported that boxers had an average 9.61 body fat percentage (Çınar et al, 2009). Savaş and Uğraş (2004) reported that eight-week pre-season training program reduced the body fat rate from $12.86 \pm 2.37$ to $12.72 \pm 2.87$ in their study of the effects on the physical and physiological characteristics of university male boxing athletes. When the values of elite boxers are compared; The body fat rate average of the Turkish National Boxing Team was found as 16.76\%, the body fat rate average of the Ukrainian Boxing National Team was 13.40\% (Çınar, 2009), the body fat rate average of Azerbaijan Boxing National Team was 10.29\% and the body fat rate average of Turkish Boxing National Team was found as 13.16\% (Beyleroğlu, 1998). Differences in body fat rate (\%) mean values can be explained by the fact that our study group is in the junior women category.

In our study, it is seen that while the average of pre-camp of the athletes was 10 meters speed and 30 speed meters ( 3.03 sec and $6.44 \mathrm{sec}$ respectively), it was (2.93 sec and $6.25 \mathrm{sec}$ respectively) after the camp, and development rate was $3 \%$. (Table2). Anaerobic power is associated with short-term rapidity (Perez-Gomez et al., 2008). In addition to determining anaerobic performance $10 \mathrm{~m}$ and $30 \mathrm{~m}$. Speed tests are also frequently used (Eyuboğlu et al., 2009). Kiyıc1 et al. (2016) found 30-ms sprint time as $5.24 \pm 0.27$ seconds when working with National women boxers who had a mean age of $20.17 \pm 3.3$ years. 26 male boxing national team athletes from the elder's category participated in a study that the correlation between elite boxers' agility, speed, reaction and vertical leaping competence were examined. A low and statistically insignificant correlation $(r=0.301, p>0.05)$ between the agility and the $30 \mathrm{~m}$ sprint test was found in the study, which indicated that the common meeting point of researchers investigating the correlation level between power, force and speed outputs and agility was low (Bayraktar, 2013). Based on our work findings, it can be explained that the decrease in body weight and body fat rate and the decrease in the speed values proportionally caused to a positive increase in speed value.

In our study, it is seen that while the athletes' pre-camp vertical jump scores were $0.21 \mathrm{~m}$, they increased to $0.31 \mathrm{~m}$ after camp, and the development rate was $48 \%$ (Table 2). Explosive muscle strength is seen as the main determinant of performance in many individual and team sports (Bayraktar, 2013). Vertical jump test is a frequently preferred test for determining of anaerobic power and capacity (Sevim, 2002; Eyuboğlu et al., 2009). Karaman (2015) reported that the vertical jump values of elite women boxers were $29.88 \mathrm{~cm}$ in his study on 14-17-year-old elite women boxers. Savaş and Uğraş (2005) determined that, in their studies that they researched the effects of six-week preliminary training program before the 2nd World Women's Boxing Championship on Turkish women national boxing team on selected physical and physiological parameters, average vertical jump value increased from 31.33 to $32.67 \mathrm{~cm}$.

Kiyıc1 et al. (2016) determined the average vertical jump (CMJ) value as $23.78 \pm 3.56 \mathrm{~cm}$ in the study of A-class national women boxers whose age average were $20.17 \pm 3.3$ years. In a study comparing some physical parameters of professional women handballers with the national female boxers, it was reported that boxers had average $42.20 \mathrm{~cm}$ vertical jump (Çınar et al., 2009). In a study that the correlations between elite boxers' speed and vertical jump ability were examined, in the study that 26 men boxing national team sportsmen in the elder category participated, it was found that there was high level, negative and significant correlation between vertical jump and sprint ability $(\mathrm{r}=-0.772$, $\mathrm{p}<0.05$ ), (Bayraktar, 2013). Serin and Taşkın (2016) found that there was a significant correlation between anaerobic endurance and vertical jump performance in their studies of correlation between anaerobic endurance and vertical jump in boxing and handballs $(\mathrm{p}<0.05)$, indicating that anaerobic performance increases as vertical jump performance increases. Pala ve Savucu (2011) defined that the vertical jump (cm) parameter of Big Men's Boxing National Team; the pre-camp was $43.05 \mathrm{~cm}$ and the post-camp value was $44.55 \mathrm{~cm}$, the increase was also statistically significant. In similar studies made on the national team boxers, similar values such as $39.57 \mathrm{~cm}, 43.45 \mathrm{~cm}$ and $47.82 \mathrm{~cm}$ were determined in the measurements of the vertical jump values of the Turkish Boxing National Team during different periods (Pala ve Savucu (2011). Based on our findings, we can say that they had a productive camp period by increasing the vertical jump parameters as well as the speed parameter.

The last finding obtained as a result of the research is the anaerobic power values of the athletes. The average pre-camp anaerobic power of the athletes was $63.71 \mathrm{kgm} / \mathrm{s}, 74.47 \mathrm{kgm} / \mathrm{s}$ after the camp, and the development rate was 17\% (Table 2). Savaş and Uğraş (2005) determined that, in the study they investigated the effects of six week preliminary training 
program before the 2nd World Women's Boxing Championship on selected physical and physiological parameters of Turkish women's national boxing team, the average anaerobic power value increased from $52.00 \mathrm{kgm} / \mathrm{s}$ to $53.57 \mathrm{kgm} / \mathrm{s}$. Kiyıc1 et al. (2016) found that the average anaerobic power value was $60.47 \pm 8.15 \mathrm{kgm} / \mathrm{s}$ in a study conducted with A national women boxer who had a mean age of $20.17 \pm 3.3$ years. With total 16 boxers, 11 of the who wore Turkish National Team Uniform, 5 of whom was the first three in the Turkish Championship, who have the degree of the World and Europe, in a study that changes and developments in some physical and respiratory parameters were investigated after 12-week training program, the pre-test anaerobic power averages of the boxers were $118.96 \mathrm{~kg} / \mathrm{s}$ and the final test averages were $119.62 \mathrm{~kg} / \mathrm{s}$ (Çakmakçı et al., 2005). Selçuk (2014) stated that it is more effective to use the fixed resistance method to perform the resistance test of boxers for boxers because of the increase of anaerobic power of fixed resistance tire exercise (Selçuk, 2014) when working with 12 women boxers at elite level between aged 19-23. Ozan (2013), 16 years old Men Boxing National Team athlete, in a study examining the anaerobic characteristics of 10 boxers, reported that the anaerobic power levels of boxers were $9.96 \mathrm{~W} / \mathrm{kg}$. Savaş and Uğraş (2004) reported that the anaerobic powers of the eight-week pre-season training program had increased from $113.35 \pm 22.29 \mathrm{~kg} / \mathrm{s}$ to $119.88 \pm 20.87 \mathrm{~kg} / \mathrm{s} \mathrm{in}$ their studies of the effects on the physical and physiological characteristics of university men boxing athletes. Our findings are similar to the literature and we can say that the athletes had a beneficial camp period positively contributing to the speed and vertical jump parameters.

In conclusion, we can say after a well-designed six-week of training camp that there are positive changes in all measured physical and biomotor features of Turkey National Junior Women's Boxing Team before the European Championships. Developments in the body weight, BMI, body fat percentages, anaerobic power, $10 \mathrm{~m}$ speed and $30 \mathrm{~m}$ speed values are interrelated with each other. These developments can improve overall performance of boxers in European Championship.

\section{References}

Aydaş, A., Uğraş, A., \& Savaş, S. (2002). Comparison of the Selected Physical and Physiological Characteristics of the Turkish National Boxing Team Members with Two Different Boxing Teams. Gazi BESBD, 7(2), 11-22.

Bayraktar, I. (2013). Relations Between Elite Boxers' Agility, Speed, Reaction and Vertical Jumping Competencies. Akademic Sight, 35(3), 1-8.

Beyleroğlu, M. (1998). Comparison of Turkey and Azerbaijan National Boxing Team Anthropometric and Physical Structure. Sakarya University, Institute of Social Sciences. M. Sc. Thesis,

Çakmakçı, O., Çınar, V., Çakmakçı, E., \& Görücü, A. (2005). Effects of 12-week Training Program on Some Physical and Physiological Parameters in the Elite Boxers. Journal of Physical Education and Sport Science,7(1), 1-6.

Çınar, V., Biçer, Y., Pala, R., \& Savucu, Y. (2009). Comparasion of the Some Physical Fitness Characteristics of Turkish and Ukraine Boxing National Team. e-Journal of New World Sciences Academy, 4(3), 154-161

Çınar, V., Polat, Y., Savucu, Y., \& Şahin, M. (2009). Investigation Some Physical Parameters of Elite Female Boxing and Handball Players. e-Journal of New World Sciences Academy, 4(3), 162-170.

Devecioğlu, S., \& Pala, R. (2010). The Contribution Body Composition of Boxers to Sportive Achievement. Firat University Medical Journal of Health Sciences, 24(2), 115-122.

Eyuboğlu, E., Özkan, A., Köklü, Y., Alemdaroğlu, U., \& Akalan, C. (2009). An Investigation of Relationship between Various Protocols of Anaerobic Performance Tests in American Football Players, Journal of Human Sciences, 6(2), 368-379

Fox, E. L, Bowers, R. W., \& Foss, L. M. (1999). Physiological Foundations of Physical Education and Sports, Bağırgan Press, Ankara, 15.

Kıyıcı, F., Taş, M., Bayraktar, I., \& Erhan, E. (2016). The Study of Relationship between Some Chosen Parameters and Anaerobic Strength Abilities of Elite Boxers. Journal of Physical Education and Sport Science, 18(2), 23-34.

Muhammed Emre Karaman. (2015). The Effect of Body Fat Percentage on Balance and Some Physical Properties of 14-17 Years Old Elite Female Boxers. Gazi University Institute of Health Sciences. M. Sc. Thesis.

Otman, S. ve ark. (1998). Tedavi Hareketlerinde Temel Değerlendirme Prensipleri. 2. Bask1. Hacettepe Üniversitesi Fizik Tedavi ve Rehabilitasyon Yüksekokulu Yayınları: 16, Ankara 50-51.

Ozan, M. (2013). Evaluation of the Anaerobic Strength in Athletes with Arm and Leg Wingate Tests. Selçuk University, Institute of Health Sciences. M. Sc. Thesis.

Pala, R., \& Savucu, Y. (2011). Examination of Some Physical and Oxidative Stress Parameters of Turkish National Boxing Team During Training Camp to European Championship. Firat University Medical Journal of Health 
Sciences, 25(3), 115-120.

Perez-Gomez, J., Rodriguez, G. V., Ara, I., Olmedillas, H., Chavarren, J., GonzálezHenriquez, J. J., ... Calbet, J. A. (2008). Role of Muscle Mass on Sprint Performance: Gender Differences?. Eurepean Journal of Applied Physiology, 102(6), 685-694. https://doi.org/10.1007/s00421-007-0648-8

Savaş, S., \& Uğraş, A. (2004). Effects of 8-Week Pre-Season Training Program on Some Physical and Physiological Characteristics of Collegiate Male Box, Taekwondo and Karate Players. Journal of Gazi Faculty of Education. 24(3), 257-274.

Savaş, S., \& Uğraş, A. (2005). Research of Physical and Physiological Properties Turkish National Boxing Team. Journal of Physical Education and Sport Science, 7(1), 1-6.

Selçuk, M. S. (2014). In Female Boxers, the Effect of Application of Resistance Band for 6 Weeks on the Maximum Force and Anaerobic Power. Selçuk University, Institute of Health Sciences. M. Sc. Thesis.

Serin, E., \& Taşkın, H. (2016). Association Between Anaerobic Endurance and Vertical Jump. Journal of Sports and Performance Researches, 7(1), 37-43.

Sevim, Y. (2002). Training Science. Nobel Press. Ankara: 233.

Tamer, K. (2000). The Evaluation and the Measurement of Physical and Physiological Performance in Sports. Bağırgan Press, Ankara.

WHO Expert Consultation (2008). Waist Circumference and Waist-Hip Ratio: 8-11 December; Geneva, Switzerland.

Zorba, E., \& Saygın, Ö. (2009). Physical Activity and Physical Fitness. İnceler Press, Ankara.

\section{Copyrights}

Copyright for this article is retained by the author(s), with first publication rights granted to the journal.

This is an open-access article distributed under the terms and conditions of the Creative Commons Attribution license which permits unrestricted use, distribution, and reproduction in any medium, provided the original work is properly cited. 